\title{
The influences of the environment and information on the complications of diabetes on patient outcomes
}

\author{
Kazuoki Inoue ${ }^{1 *}\left(\mathbb{D}\right.$, Jun Watanabe ${ }^{2}$ and Eiichi Kakehi ${ }^{3}$
}

\begin{abstract}
This letter was written to address two concerns about the results of the paper published by Zeynep et al. (BMC Health Qual Life Outcomes 18:265, 2020). First, the differences between the two groups in the environment with or without occupation may strengthen the primary outcome results. Second, lack of information on the complications and treatments of diabetes makes interpretation of the results difficult.
\end{abstract}

Keywords: Diabetes mellitus, Occupation-based, Problem-solving, Quality of life

\section{Dear Editor,}

We read with great interest this study, which clarified the effects of problem-solving therapy (PST) on the occupational performance, self-efficacy, and well-being of type 2 diabetic patients in Turkey [1]. However, we have two concerns about the methodology of this study.

First, the difference between the two groups in terms of whether they were in an environment with or without occupation might have significantly affected the results, so the results should be subtracted. In this study, although the participants were randomly assigned at Baseline, more participants in the intervention group than in the control group were engaged in work. Therefore, the Canadian Occupational Performance Measure (COPM) for primary outcomes is more likely to have a stronger effect on the amount of change because it affects the client's environment [2]. The COPM is a questionnaire that asks about self-perceptions of occupational performance. Participants in the environment with

\footnotetext{
*Correspondence: kishindesu@gmail.com

${ }^{1}$ Department of Community-Based Family Medicine, Faculty of Medicine,

School of Medicine, Tottori University, 86 Nishi-cho, Yonago-City, Tottori 683-8503, Japan

Full list of author information is available at the end of the article
}

occupation might find it easier to visualize and practice "problem definition," "generation of alternatives," "decision-making," "solution implementation and verification," in PST.

Second, this study does not describe the complications and treatment of diabetes, which we would like to know about. Hypoglycemia, a complication of diabetes, is said to reduce the work productivity of diabetic patients [3]. In addition, patients with type 2 diabetes are limited by the social and emotional aspects of insulin therapy [4]; they refuse insulin therapy because they feel that starting insulin will stigmatize them socially [5]. Thus, depending on the complications and treatment of diabetes, the results of this study may be weakened.

\section{Abbreviations \\ PST: Problem-solving therapy; COPM: The Canadian Occupational Perfor- mance Measure.}

\section{Acknowledgements}

Not applicable.

\section{Authors' contributions}

All authors discussed the study. All authors read and approved the final manuscript.

Funding

Not applicable.

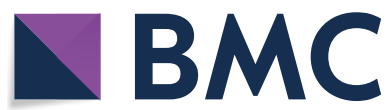

(c) The Author(s) 2021. This article is licensed under a Creative Commons Attribution 4.0 International License, which permits use, sharing, adaptation, distribution and reproduction in any medium or format, as long as you give appropriate credit to the original author(s) and the source, provide a link to the Creative Commons licence, and indicate if changes were made. The images or other third party material in this article are included in the article's Creative Commons licence, unless indicated otherwise in a credit line to the material. If material is not included in the article's Creative Commons licence and your intended use is not permitted by statutory regulation or exceeds the permitted use, you will need to obtain permission directly from the copyright holder. To view a copy of this licence, visit http://creativecommons.org/licenses/by/4.0/. The Creative Commons Public Domain Dedication waiver (http://creativecommons.org/publicdomain/zero/1.0/) applies to the data made available in this article, unless otherwise stated in a credit line to the data. 


\section{Availability of data and materials}

Date sharing is not applicable to this article as no datasets were generated or analyzed during the present study.

\section{Ethics approval and consent to participate}

Not applicable.

\section{Consent for publication}

Not applicable.

\section{Competing interests}

The authors declare that they have no competing interests.

\section{Author details}

'Department of Community-Based Family Medicine, Faculty of Medicine, School of Medicine, Tottori University, 86 Nishi-cho, Yonago-City, Tottori 683-8503, Japan. ${ }^{2}$ Division of Community and Family Medicine, Jichi Medical University, 3311-1 Shimotsuke-City, Tochigi 329-0498, Japan. ${ }^{3}$ Tottori Municipal Hospital, 1-1 Matoba, Tottori-City, Tottori 680-8501, Japan.

Received: 2 March 2021 Accepted: 3 June 2021

Published online: 08 June 2021

\section{References}

1. Ağce ZB, Ekici G. Person-centred, occupation-based intervention program supported with problem-solving therapy for type 2 diabetes: a randomized controlled trial. BMC Qual Life Outcomes. 2020;18:265. https://doi.org/10.1186/s12955-020-01521-x.

2. Enemark Larsen A, Rasmussen B, Christensen JR. Enhancing a clientcentred practice with the Canadian Occupational Performance Measure. Occup Ther Int. 2018;2018:5956301. https://doi.org/10.1155/2018/59563 01.

3. Fulcher G, Singer J, Castañeda R, Filho FF, Maffei L, Snyman J, Brod M. The psychosocial and financial impact of non-severe hypoglycemic events on people with diabetes: two international surveys. J Med Econ. 2014;17(10):751-61. https://doi.org/10.3111/13696998.2014.946992.

4. Reis ACD, Cunha MV, Bianchin MA, Freitas MTR, Castiglioni L. Comparison of quality of life and functionality in type 2 diabetics with and without insulin. Rev Assoc Med Bras. 2019;65(12):1464-9.

5. Raghavendran S, Inbaraj LR, Norman G. Reason for refusal of insulin therapy among type 2 diabetes mellitus patients in primary care clinic in Bangalore. J Family Med Prim Care. 2020;9(2):854-8.

\section{Publisher's Note}

Springer Nature remains neutral with regard to jurisdictional claims in published maps and institutional affiliations.
Ready to submit your research? Choose BMC and benefit from:

- fast, convenient online submission

- thorough peer review by experienced researchers in your field

- rapid publication on acceptance

- support for research data, including large and complex data types

- gold Open Access which fosters wider collaboration and increased citations

- maximum visibility for your research: over $100 \mathrm{M}$ website views per year

At BMC, research is always in progress.

Learn more biomedcentral.com/submissions 